\title{
A MODEL APPROACH TO DISTINGUISH DIPLOID AND TRIPLOID FISH BY MEANS OF COMPUTER-ASSISTED IMAGE ANALYSIS
}

\author{
M. FLAJŠHANS \\ Department of Fish Genetics and Breeding. \\ Research Institute of Fish Culture and Hydrobiology, \\ University of South Bohemia, Vodňany, Czech Republic \\ Received February 11, 1997 \\ Accepted June 17, 1997
}

\begin{abstract}
Flajšhans M.: A Model Approach to Distinguish Diploid and Triploid Fish by Means of Computer-assisted Image Analysis. Acta vet. Brno 1997, 66: 101-110.

A model approach to distinguish diploid and triploid fish rapidly upon computer-assisted image analysis of erythrocyte nuclear dimensions in blood smear samples was exemplified on measurements of 13 diploid and 13 artificially-induced triploid wels (Silurus glanis). Analysis of variance test confirmed that nuclear area, perimeter, nuclear major axis and average nuclear size were the decisive dimensions for such approach $(\mathrm{P}<0.0001)$. The respective values (mean $\pm \mathrm{SD})$ for diploids and triploids were registered as follows: nuclear area $11.09 \pm 1.26 \mu \mathrm{m}^{2}$ and 17.34 $\pm 2.09 \mu \mathrm{m}^{2}$; nuclear perimeter $12.67 \pm 0.80 \mu \mathrm{m}$ and $16.24 \pm 1.07 \mu \mathrm{m}$; nuclear major axis 4.62 $\pm 0.35 \mu \mathrm{m}$ and $6.17 \pm 0.47 \mu \mathrm{m}$ and average nuclear size $4.01 \pm 0.22 \mu \mathrm{m}$ and $5.12 \pm 0.31 \mu \mathrm{m}$. This approach was found a rapid and precise alternative to other currently used methods of ploidy level identification in fish.
\end{abstract}

Triploidy, image analysis, erythrocytes, nuclear dimensions, Silurus glanis

The differences in erythrocyte cellular and nuclear dimensions between diploid and triploid fish have been firstly registered by Swarup (1959). Sezaki and Kobayasi (1978) and Le moine and S mith (1980) have proposed a computation of cellular and nuclear area and volume from major and minor cellular and nuclear axes of diploid and polyploid fish. Later on, Wolters et al. (1982) and B enfey et al. (1984) proposed that identification of triploids could be based solely on measuring the erythrocyte nuclear major axis. To the best of my knowledge, computer - assisted image analysis of erythrocyte nuclei was used for identification of polyploid fish yet by Cormier et al. (1993) only, for comparison of this technique as an alternative to flow cytometry and Coulter Counter for triploidy identification in brown bullhead, Ameiurus nebulosus.

The goal of this paper was to use, describe and evaluate this innovative approach, the computer-assisted image analysis for discrimination of ploidy level based on erythrocyte nuclear dimensions. Diploid and triploid wels, Silurus glanis, was used as a model species.

\section{Materials and Methods}

Triploid wels were produced at Anjou Fish Culture at Morannes, France, by heat shock as described by Lin h a r $t$ and Flajšhans (1995). Ploidy level of the fish was firstly assessed by flow cytometry at Angers University, Angers, France, according to Vindelov and Christensen (1990) and 13 diploid and 13 triploid yearlings were kept separately for this study. Blood was sampled from the caudal vessel into heparinized syringe and blood smears were prepared on microscopic slides according to S v obodov á et al. (1986), then fixed with methanol. Slides were stained with $20 \%$ Giemsa stain in Sörrensen`s phosphate buffer ( $\mathrm{pH} 6.8$ ).

Computer-assisted image analyses were carried out at the Department of Fish Genetics and Breeding. Research Institute of Fish Culture and Hydrobiology, University of South Bohemia, Vodňany. Czech Republic. The entire 
system was set up by Olympus C \& S and consisted of an Olympus BHS microscope. coupled Sony XC-75CE camera, Sony video monitor and PC-486 computer. Software used was CUE-2 by Galai Inc., Israel. Slides were scored under objective magnification $\times 100$ with oil immersion. Erythrocyte nuclei were measured after setting up the threshold level to cover the contrast objects only. After preliminary tests (Flajšhans and Jendrůlek, unpublished data), shape filter (i.e. filter to pass the pre-selected objects only) was defined by area $\left(6.00-25.00 \mu \mathrm{m}^{2}\right)$ and shape factor $(0.65$ 1.00). Other equally stained blood cells (e.g. erythroblasts, monocytes, thrombocytes) were eliminated from the image. The programme was adjusted to analyze the following dimensions of 200 and more erythrocyte nuclei in every fish: area, perimeter, major axis recorded as maximum Feret's diameter, minor axis as minimum Feret's diameter and average size as average Feret's diameter. Every Feret's diameter, defined in the software, was computed as an average of 32 consequent measurements under an increasing angle. Triploid/diploid ratio was computed additionally. Results were processed in dBASE 1.5 programme. Analysis of variance (ANOVA) followed by Scheffe's test in Statgraphics 5.0 was used to investigate the effect of ploidy level on the respective erythrocyte nuclear dimensions.

\section{Results}

In all fish under study, the effect of ploidy on erythrocyte nuclear dimensions corresponded to their relative DNA content which has been firstly assessed by flow cytometry. No diploid/triploid mosaicism was found. Thin blood smears with a monolayer of not overlapping erythrocytes were found to be the necessary prerequisite for both staining and analysis procedures. The image-analyzed erythrocyte nuclei of triploid wels were of

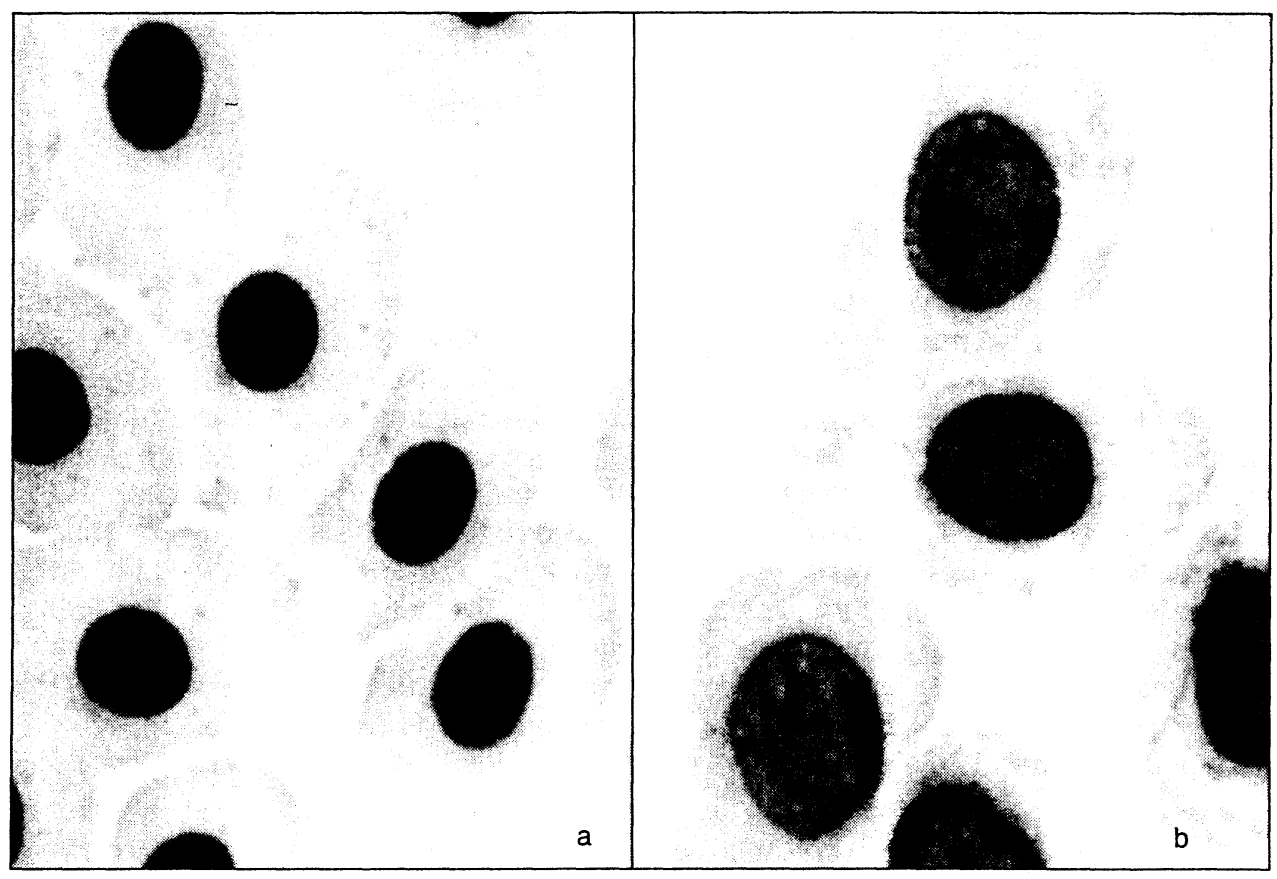

$10 \mu \mathrm{m}$

Fig. 1. Computerized image of erythrocytes of diploid a) and triploid b) wels, Silurus glanis. 
$1.56 \times$ larger nuclear area, $1.28 \times$ larger nuclear perimeter, $1.28 \times$ larger average nuclear size, $1.34 \times$ larger major nuclear axis and $1.15 \times$ larger minor nuclear axis than those of diploids. The difference is evident from Fig. 1. The respective data on erythrocyte nuclear dimensions analyzed and ratios computed are given in Table 1.

Table 1

Basic dimensions of erythrocyte nuclei of diploid and triploid wels, Silurus glanis L. investigated by image analysis (I) and their computed derivative ratios (C)

\begin{tabular}{|lccc|}
\hline & $\begin{array}{c}\text { Diploids } \\
(\text { Mean } \pm \text { SD })\end{array}$ & $\begin{array}{c}\text { Triploids } \\
(\text { Mean } \pm \text { SD })\end{array}$ & $\begin{array}{c}\text { Triploid/Diploid } \\
\text { Ratio }(\mathrm{C})\end{array}$ \\
\hline No. of Fish Analyzed & 13 & 13 & \\
No. of Nuclei Analyzed & 2648 & 2668 & \\
Nuclear Area $\left(\mu \mathrm{m}^{2}\right)(\mathrm{I})$ & $11.09 \pm 1.26$ & $17.34 \pm 2.09$ & 1.56 \\
Nuclear Perimeter $(\mu \mathrm{m})(\mathrm{I})$ & $12.67 \pm 0.80$ & $16.24 \pm 1.07$ & 1.28 \\
Average Nuclear Size $(\mu \mathrm{m})(\mathrm{I})$ & $4.01 \pm 0.22$ & $5.12 \pm 0.31$ & 1.28 \\
Nuclear MajorAxis $(\mu \mathrm{m})(\mathrm{I})$ & $4.62 \pm 0.35$ & $6.17 \pm 0.47$ & 1.34 \\
Nuclear Minor Axis $(\mu \mathrm{m})(\mathrm{I})$ & $3.26 \pm 0.29$ & $3.75 \pm 0.38$ & \\
\hline
\end{tabular}

The differences of erythrocyte nuclear dimensions (area, perimeter, average size and major axis) between the samples of diploids and triploids were found statistically significant (ANOVA, P < 0.01). Moreover, ANOVA test confirmed a highly significant effect of ploidy level (diploidy, triploidy) on the dimensions of erythrocyte nuclear area, nuclear perimeter, average nuclear size and/or major nuclear axis size ( $P<0.0001$; Figs. 2 - 4 and Fig. 6).

Differences among fish within a common ploidy level (i.e. among diploids and among triploids) were also proven (ANOVA; $\mathrm{P}<0.01$ ).

The effect of ploidy level on the dimension of erythrocyte nuclear minor axis was not found significant (ANOVA; P > 0.05, Fig. 5).

\section{Discussion}

Relatively high differences in means of erythrocyte nuclear area, major- and minor axis were found compared to original data of $\mathrm{Kr}$ a s z na i et al. (1984) for this species. It can be hypothesized that these differences between both studies could be affected by sample size and/or variation in the respective dimensions [ 20 erythrocytes per fish by $\mathrm{Kr}$ a s z $\mathrm{n}$ a $\mathrm{i}$ et al. (1984) vs. 200 erythrocytes per fish under study]. Moreover, it is known that nuclear size can vary with a number of factors including cell age (Cormier et al. 1993). Although erythrocyte developmental stages (erythroblasts) were excluded from the image in this study, variation in the particular dimensions was observed within the blood samples of diploid and/or triploid fish.

Mean erythrocyte nuclear area by $\mathrm{Kr}$ a s z $\mathrm{n}$ a i et al. (1984a) was calculated from formula according to Sezaki and Kobay asi (1978), i.e. they considered identical conditions for all nuclei. It reached $8.6 \pm 0.9 \mu \mathrm{m}^{2}$ for diploids and $11.5 \pm 1.2 \mu \mathrm{m}^{2}$ for triploids. Compared to data under study measured by image analysis directly, these values were based on measurement of every cell under image and it therefore registered deviations from the ideal shape. Mean values were of $2.49 \mu \mathrm{m}^{2}$ and $5.84 \mu \mathrm{m}^{2}$ larger area for diploids and triploids, respectively. Triploid/diploid ratio of nuclear area by Kras znai et al. (1984) was 1.32 compared to currently computed value 1.56 . The latter, as well as nuclear area 


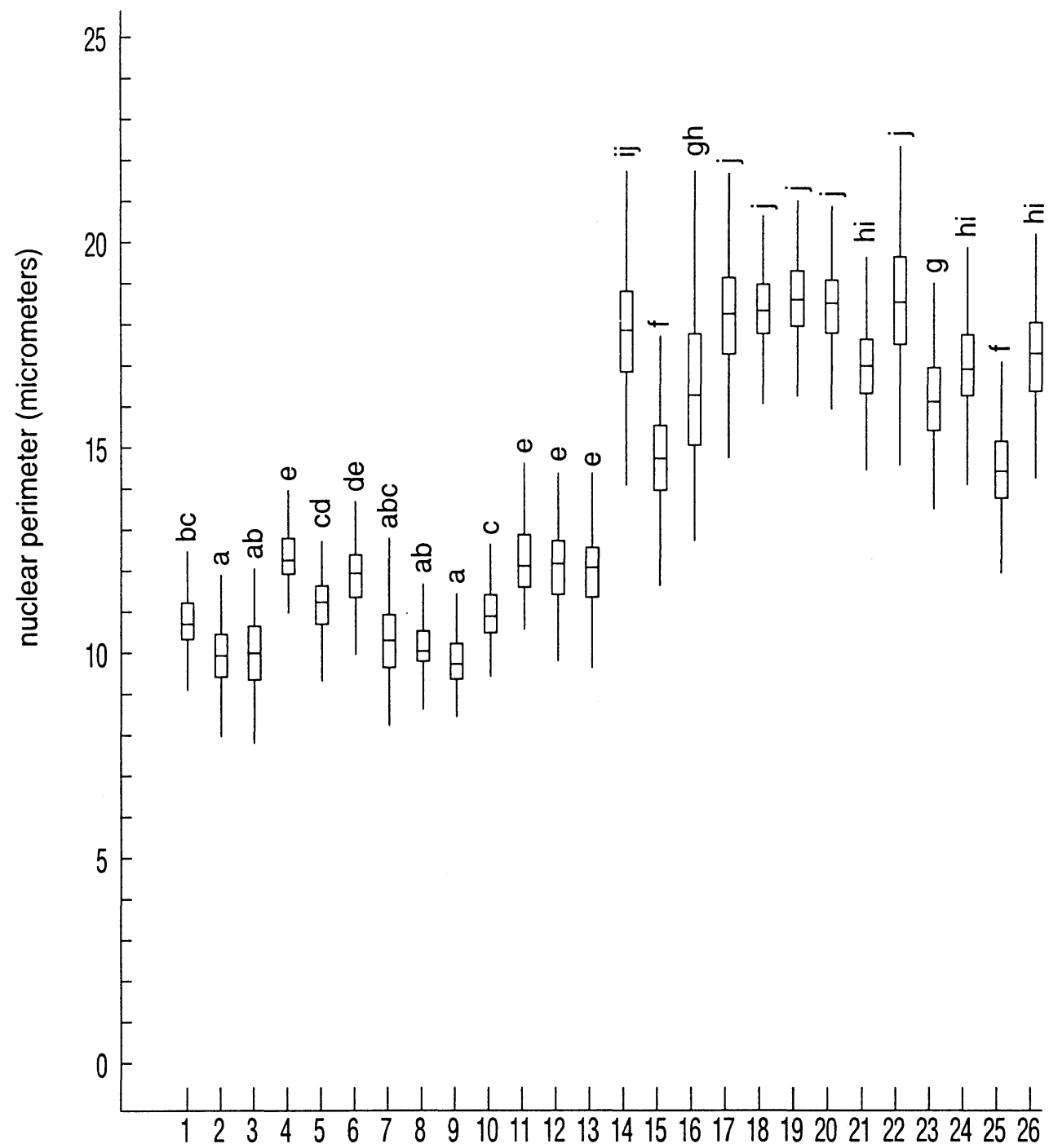

1 to 13 diploids, 14 to 26 triploids

Fig. 2. ANOVA means plot of nuclear area of 2648 erythrocytes from 13 diploid and of 2668 erythrocytes from 13 triploid wels, Silurus glanis. Figures with common superscript do not differ significantly at $\mathrm{P}<0.01$.

dimensions were also closer to findings of Cormier et al. (1993) in image analysis of brown bullhead.

It can be stated in accordance with Krasznai et al. (1984) and Krasznai and M a ri a n (1986) that erythrocyte nuclei of triploid wels differ significantly in mean size of nuclear major axis from those of diploids, even if maxima in distribution of this dimension in diploids can slightly overlap with minima in triploids, and they can be used for 


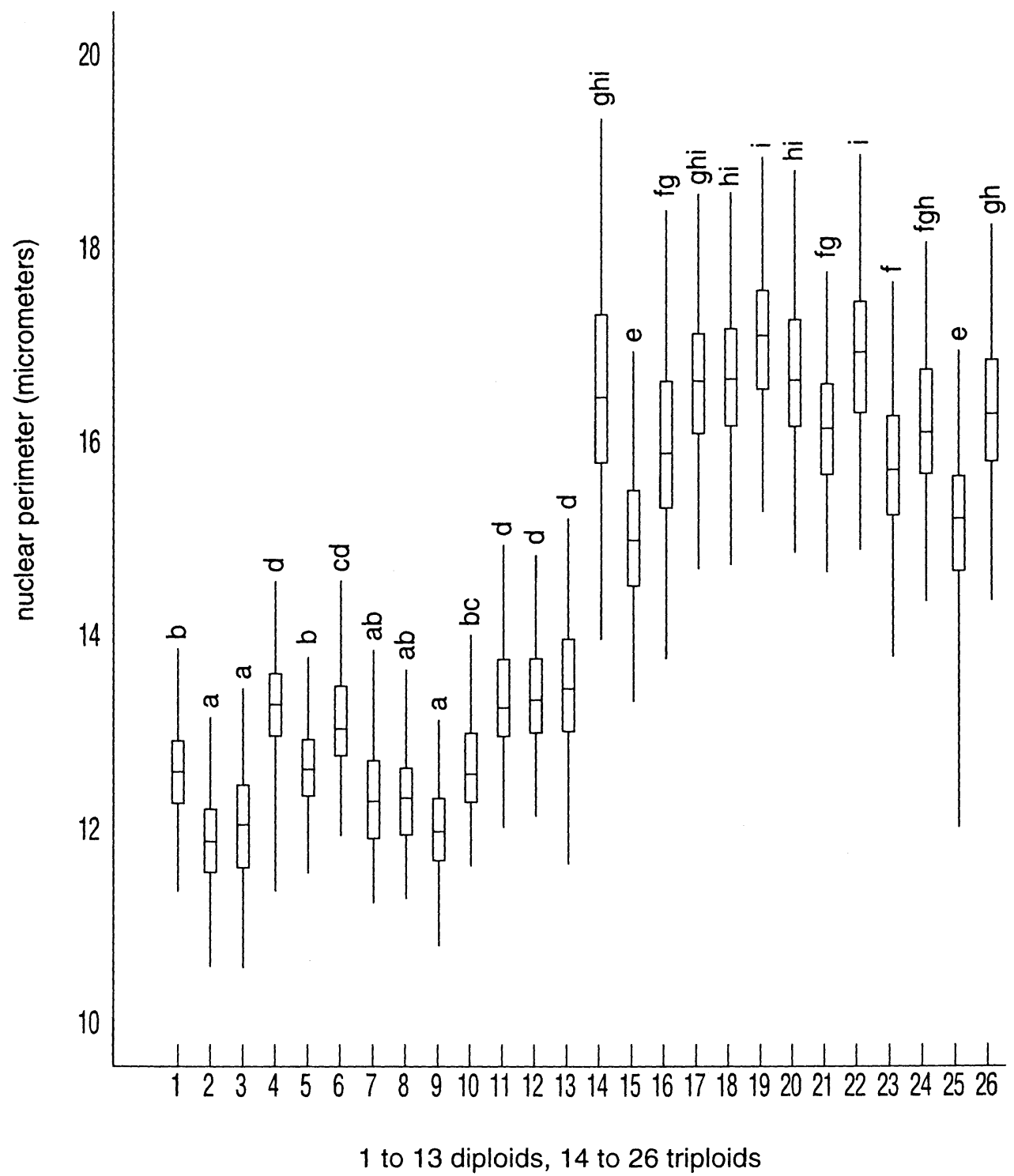

Fig. 3. ANOVA means plot of nuclear perimeter of 2648 erythrocytes from 13 diploid and of 2668 erythrocytes from 13 triploid wels, Silurus glanis. Figures with common superscript do not differ significantly at $P<0.01$.

identification of triploidy. This fact was also confirmed by Ue no (1984) and Che rf a s et al. (1991) in common carp, Cyprinus carpio L. Similar conclusions imply also to erythrocyte nuclear area.

This study did not confirm statistically the reliability of nuclear minor axis size for identification of triploidy. Generally, this dimension is considered as a very poor predictor of ploidy level (B enfey et al. 1984; Krasznai et al. 1984). 


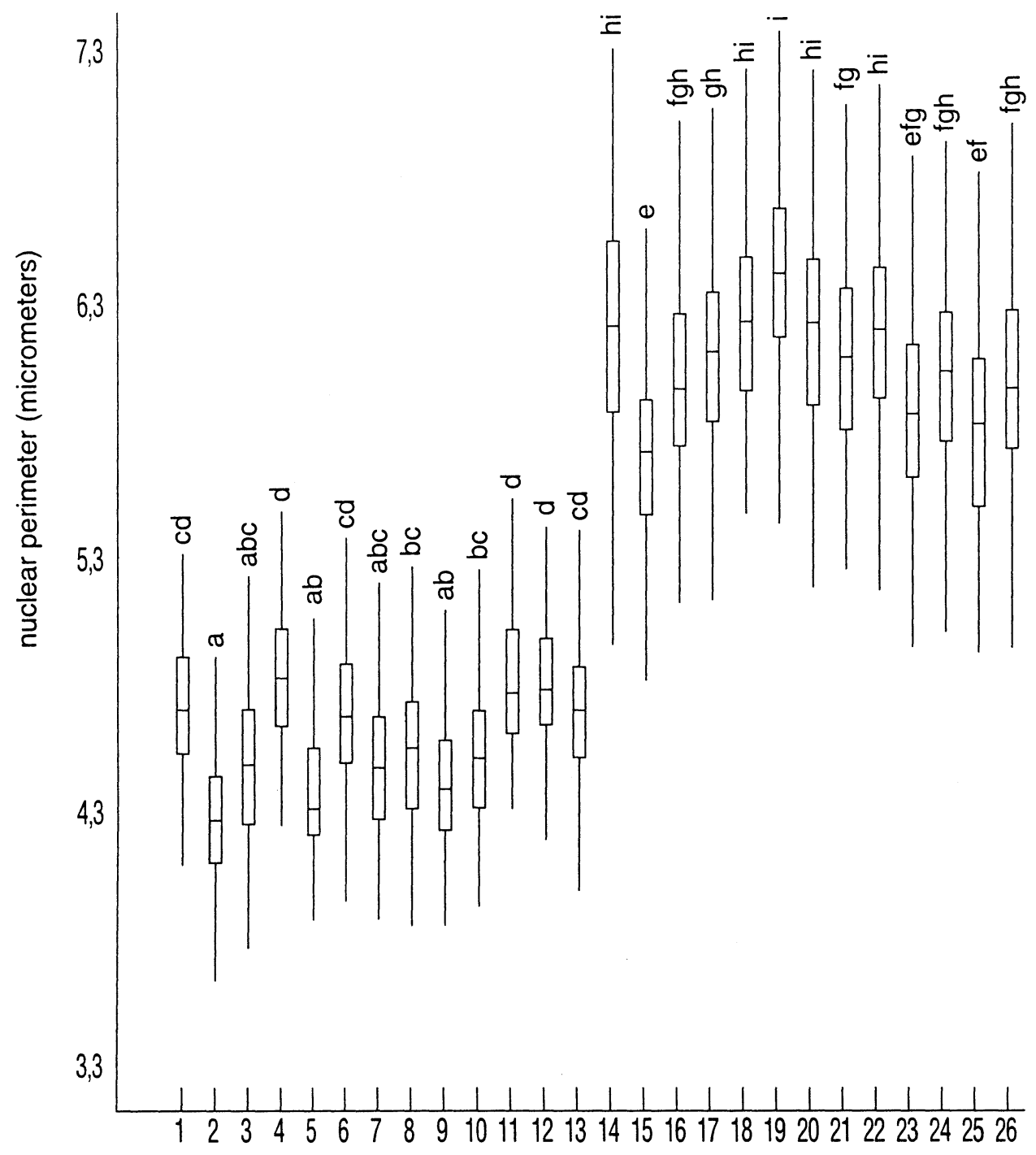

1 to 13 diploids, 14 to 26 triploids

Fig. 4. ANOVA means plot of nuclear major axis of 2648 erythrocytes from 13 diploid and of 2668 erythrocytes from 13 triploid wels, Silurus glanis. Figures with common superscript do not differ significantly at $P<0.01$.

Erythrocyte nuclear perimeter and average nuclear size of diploid and triploid wels under study were also proven to be significantly dependent on ploidy level and reliable for identification of triploidy. These results were not comparable to any previous study, since these values have never been used before.

B e $\mathrm{nfe}$ y et al. (1984) proposed that identification of triploids could be based solely on measuring the nuclear major axis, arguing that calculation of cell surface area (or nuclear 


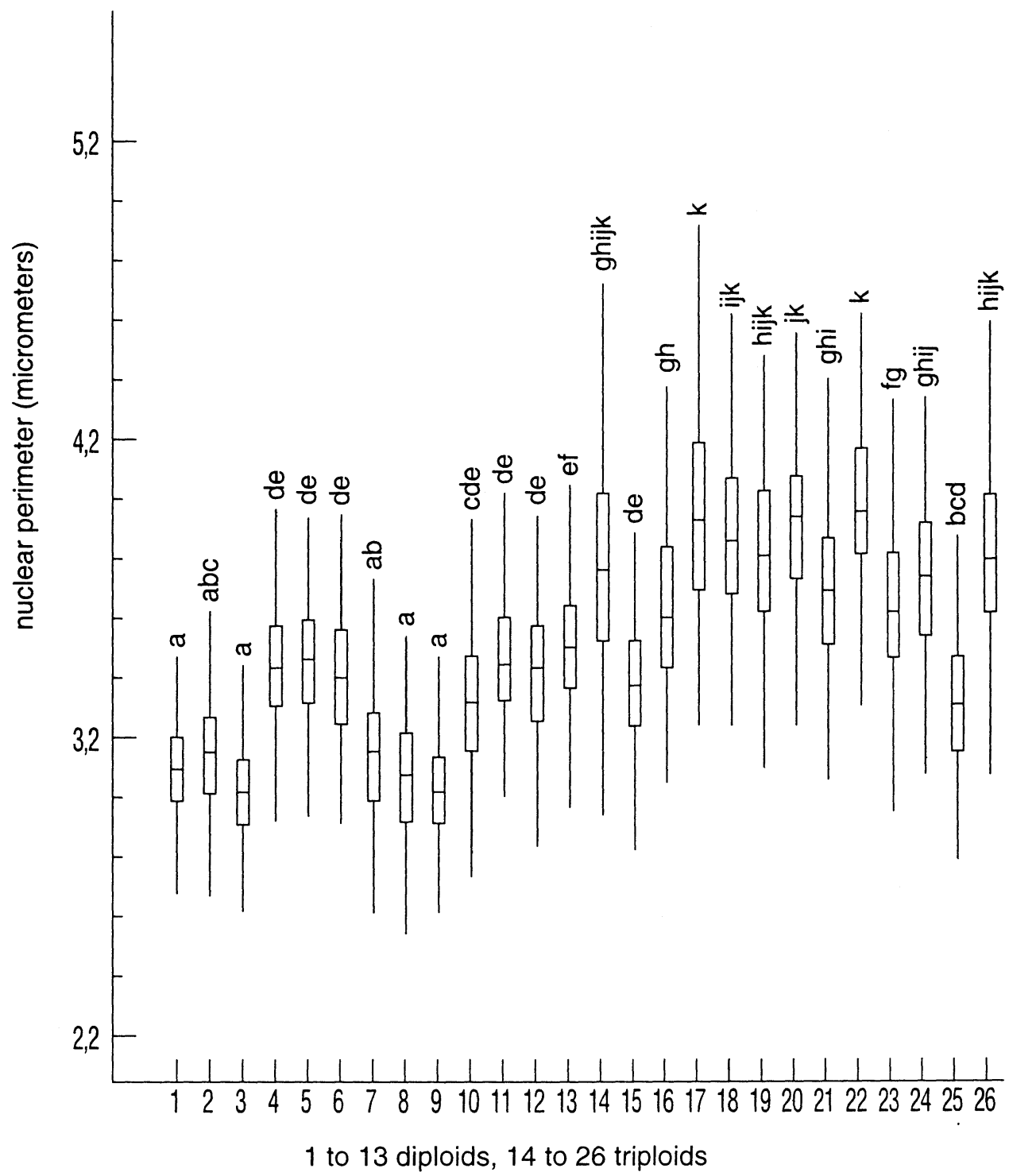

Fig. 5. ANOVA means plot of nuclear minor axis of 2648 erythrocytes from 13 diploid and of 2668 erythrocytes from 13 triploid wels, Silurus glanis. Figures with common superscript do not differ significantly at $\mathrm{P}<0.05$.

volume) which would necessitate measurement of the minor axis, would not increase the probability of correct triploid identification.

In contrary, the image analysis measures nuclear area field-specifically in machine units (pixels) and does not compute the result from Feret's diameters (nuclear major and minor axis) which are measured separately (Bradbury 1989; Jendrủlek, personal communication 1994) as parallel values. The resulting nuclear area value is then given in 


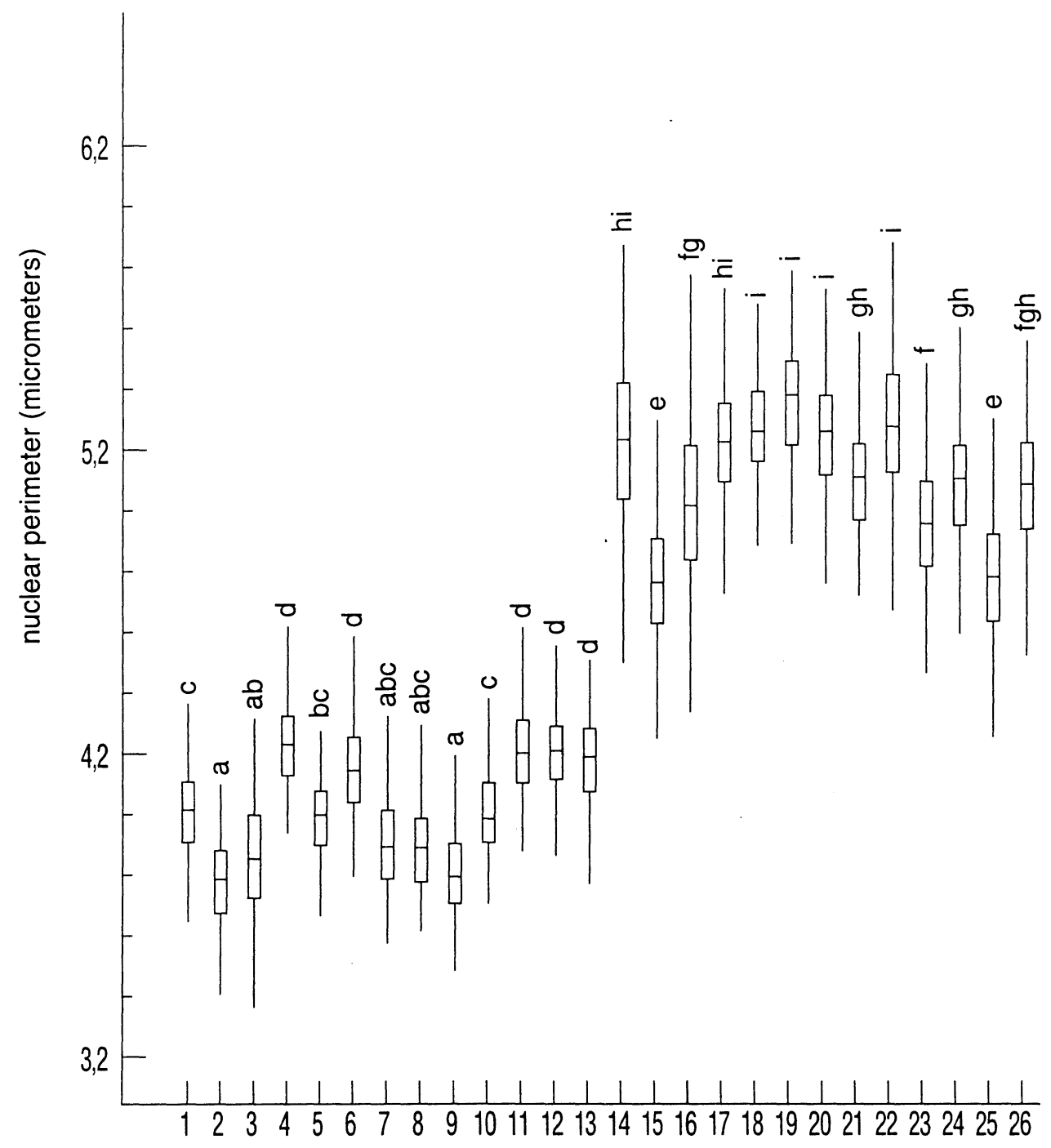

1 to 13 diploids, 14 to 26 triploids

Fig. 6. ANOVA means plot of average nuclear size of 2648 erythrocytes from 13 diploid and of 2668 erythrocytes from 13 triploid wels, Silurus glanis. Figures with common superscript do not differ significantly at $P<0.01$.

calibrated absolute units (e.g. $\mu \mathrm{m}^{2}$ ). It therefore considers the real nuclear shape, not only the standardized one as in case of using a standard formula for calculation. Moreover, both mean nuclear major and minor axes can be computed from 4 - 32 Feret's diameters so that the set up can bring precise results.

According to Plo e m (1989), image analysis also has more sophisticated procedures for rejection of artifacts than flow cytometry. The latter also does not allow visual reallocation 
of positively analyzed cells. This makes image analysis more suitable for detection of rare cells and/or for special measurements.

Thin, best quality blood smears without overlapping cells should be well differentially Giemsa - stained for image analysis. This step was found essential, since imprecise staining would cause imprecise thresholding. Once sampled, fixed and stained, blood smears were permanent and could be used repeatedly.

\section{Modelový přístup $\mathrm{k}$ rozlišení diploidních a triploidních ryb pomocí počítačové analýzy obrazu}

Modelový přístup k rychlému rozlišeni diploidních a triploidních ryb pomocí počítačové analýzy obrazu $\mathrm{z}$ rozměrů jader erythrocytů z krevních nátěrů byl předveden na základě měření buněk 13 diploidnich a 13 uměle indukovaných triploidních sumcủ (Silurus glanis). Test analýzou rozptylu potvrdil, že velikost plochy jádra erytrocytu, obvod jádra, délka dlouhé osy jádra a jeho průměrná velikost jsou rozhodujícími rozlišujícími rozměry $(\mathrm{P}<0.0001)$. U diploidních a triploidních jedinců byly zjištěny tyto hodnoty (průměr \pm směrodatná odchylka): plocha jádra erytrocytu $11,09 \pm 1.26 \mu \mathrm{m}^{2}$, resp. $17,34 \pm 2,09 \mu \mathrm{m}^{2}$; obvod jádra erytrocytu $12,67 \pm 0.80 \mu \mathrm{m}$, resp. $16,24 \pm 1,07 \mu \mathrm{m}$; délka dlouhé osy jádra erytrocytu $4,62 \pm 0,35 \mu \mathrm{m}$, resp. $6,17 \pm 0,47 \mu \mathrm{m}$; a průměrná velikost jádra erytrocytu $4,01 \pm 0,22 \mu \mathrm{m}$, respektive $5,12 \pm 0,31 \mu \mathrm{m}$. Tento přistup byl shledán rychlou a přesnou alternativou vủči ostatním v současnosti používaným metodám identifikace hladiny ploidie u ryb.

\section{Acknowledgements}

This work was carried out within the scope of CEC grant No. CIPA - CT93 - 0274 and supported by fellowship from the National Museum of Natural History in Paris, France. Thanks are due to Prof. Roland Billard from this museum for his very kind help and to Dr. Otomar Linhart from the Angers University, France, for providing the material and for the flow cytometric analyses. The author is deeply indebted to Dr. Tomáš Jendrulek from Olympus C \& S Ltd., Prague, Czech Republic for setting up the entire image analysis system and for his kind patience when teaching and training the author how to operate it.

\section{References}

BENFEY, T. J., SUTTERLIN, A. M., THOMPSON, R. J. 1984: Use of erythrocyte measurements to identify triploid salmonids. Can. J. Fish. Aquat. Sci. 41:980-984

BRADBURY, S. J. 1989: Micrometry and image analysis. In: LACEY, A. J. (ed.) Light Microscopy in Biology: A Practical Approach, IRL Press, pp. 187-220

CHERFAS, N. B., ROTHBARD, S., HULATA, G., KOZINSKY, O. 1991: Spontaneous diploidization of maternal chromosome set in ornamental (koi) carp, Cyprinus carpio L. J. Appl. Ichthyol. 7:72-77

CORMIER, S..M., NEIHEISEL. T. W.. WILLIAMS, D. E., TIERSCH, T. R. 1993: Natural occurrence of triploidy in a wild brown bullhead. Trans. Am. Fish. Soc. 122:390-392

KRASZNAI, Z., MÁRIÁN, T., KOVÁCS, G. 1984: Production of triploid European catfish (Silurus glanis L.) by cold shock. Aquacultura Hungarica (Szarvas) Vol. IV:25-32

LEMOINE, L. H., SMITH. T. L. 1980: Polyploidy induced in brook trout by cold shock. Trans. Am. Fish. Soc. 109:626-631

LINHART, O., FLAJŠHANS, M. 1995: Triploidization of European catfish, Silurus glanis L., by heat shock. Aquaculture Research 26:367-370

PLOEM, J. S. 1989: Fluorescence microscopy. In: LACEY, A. J. (ed.) Light Microscopy in Biology: A Practical Approach, IRL Press, pp. 163-185

SEZAKI, K., KOBAYASI, H. 1978: Comparison of erythrocytic size between diploid and tetraploid in Spinous Loach, Cobitis biwae. Bull. Jap. Soc. Sci. Fish. 44:851-854

SVOBODOVÁ, Z., PRAVDA, D., PALÁČKOVÁ, J. 1986: Unified methods of haematological examination of fish. Edition of Manuals, Res. Inst. Fish. Cult. Hydrobiol., Vodňany, 36 p. (in Czech).

SWARUP, H. 1959: Effect of triploidy on the body size, general organization and cellular structure in Gasterosteus aculeatus (L.). J. Genet. 56:143-155 
UENO, K. 1984: Induction of triploid carp and their haematological characteristics. Jap. J. Genet. 59, 6:585 -591

VINDELOV, L. L., CHRISTENSEN, I. J. 1990: Review of techniques and results obtained in one laboratory by an integrated system of methods designed for routine clinical flow cytometric DNA analysis. Cytometry 11: 753770

WOLTERS, W. R., CHRISMAN, C. L., LIBEY, G. S. 1982: Erythrocyte nuclear measurements of diploid and triploid channel catfish, Ictalurus punctatus (Rafinesque). J. Fish Biol. 20:253-258

Address for correspondence:

Ing. Martin Flajšhans

Research Institute of Fish Culture and Hydrobiology

University of South Bohemia

38925 Vodñany

Czech Republic

tel. +420342382402

fax. +420342382396 